\title{
DISEASE
}

\section{WEST NILE VIRUS IN WILD BIRDS IN SASKATCHEWAN: SUMMARY OF AN OUTBREAK YEAR AND POTENTIAL IMPACTS ON BIRDS}

ALEKSIJA NEIMANIS, Canadian Cooperative Wildlife Health Centre, Western College of Veterinary Medicine, 52 Campus Dr., Saskatoon, SK, S7N 5B4, Email: <aleksija.neimanis@usask.ca>

\section{Introduction}

Most North Americans are familiar with West Nile Virus (WNV), its recent introduction into North America, and the serious disease that it can cause in people. This virus is transmitted primarily by infected mosquitoes, and in temperate climates like Saskatchewan, this occurs in summer and fall when mosquitoes are active. ${ }^{4}$ Although human infections receive much attention, the primary hosts are wild birds, and human cases follow WNV cycles in these wild species (Figure 1). To better understand the activity and distribution of WNV in Canada, the Canadian Cooperative Wildlife Health Centre (CCWHC) has been working with governmental agencies to track WNV in wild birds since $2000 .^{2}$

The virus first was detected in Saskatchewan in 2002, and in 2003,

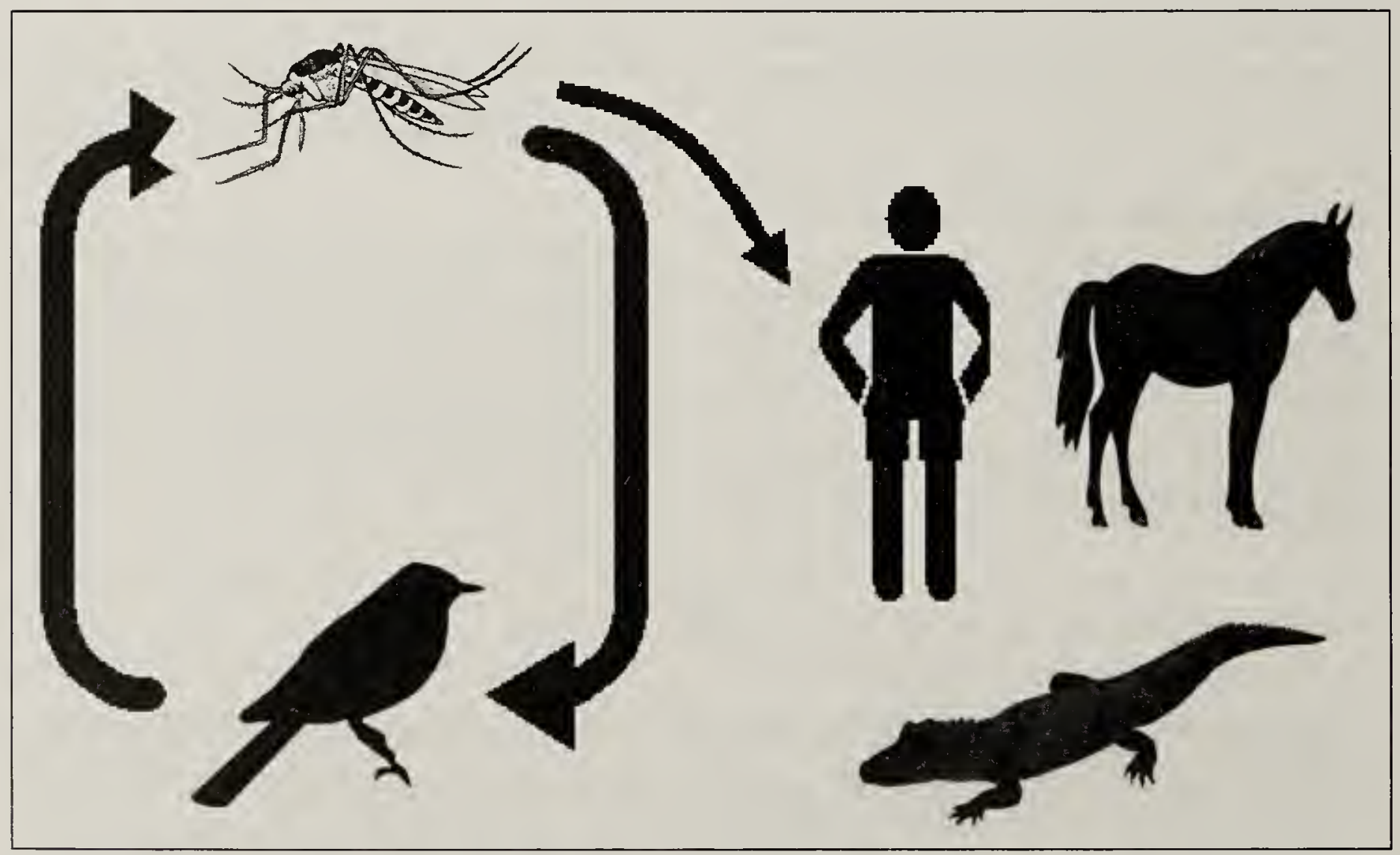

Figure 1. The West Nile Virus life-cycle. The virus circulates between birds and mosquitoes. Occasionally, mosquitoes infect humans, other mammals and reptiles. 
large numbers of infections were seen in both wild birds and humans in the province. The following years saw little WNV activity. Then, in 2007, Saskatchewan held the dubious honour of having the highest number of human cases $(1,422)$ of WNV reported in Canada for that season. ${ }^{10}$ In 2007, numerous wild birds in Saskatchewan also were infected with WNV. This article provides a summary of WNV in wild birds of Saskatchewan during this outbreak year, and discusses the impacts of this virus on wild birds.

\section{West Nile Virus detection in wild birds}

From June through October, 2007, 390 dead wild birds from Saskatchewan were submitted to the CCWHC in Saskatoon to determine cause of death. All members of the corvid (crow) family, and any additional species with microscopic findings that might suggest a WNV infection, were tested for the presence of WNV. Diagnosis was made using anti-WNV antibodies to detect virus in the oral cavity (VecTest enzyme linked immunosorbent assay) or in tissues (immunohistochemistry), and/or by using genetic techniques (polymerase chain reaction) to detect virus in tissues.

WNV was detected in 111 of these birds (see Table 1). Infected birds represented 15 different species, and the majority were corvids $(n=72)$ and birds of prey $(n=30)$. Waterbirds, an upland game bird and a songbird also were represented $(n=9)$. The first bird of the season detected with WNV was an American Crow that died on July 3 , 2007 and the last was a Red-tailed Hawk found on October 30, 2007.

\section{How WNV affects wild birds}

Bird species vary both in their susceptibility to infection by WNV, and in the degree of illness that infection causes. For example, corvids are extremely susceptible and mortality rates are high. Death rates of infected crows have ranged from $40-68 \%$ in the wild, ${ }^{1,12}$ and up to $100 \%$ in laboratory studies. ${ }^{6}$ This was consistent with findings in Saskatchewan where 72 of the 111 dead birds documented with infection were corvids. Birds of prey also are highly susceptible, and 20 of $25(80 \%)$ Merlins found dead in the summer and fall of 2007 in Saskatchewan died from WNV. Other species such as Rock Pigeons can become infected, but any resulting disease is mild. ${ }^{6}$ The impact of WNV on these birds is less clear. These birds still must mount an immune response to combat the infection. This requires energy, and this energy may be diverted from other activities such as growth and reproduction. Effects such as these are subtle, and require years of close monitoring of populations to be detected.

WNV infection can have other consequences on the health of birds. Infection may predispose birds to other injuries or disease. Many birds infected with WNV in Saskatchewan in 2007 also had other, concurrent, problems. For example, twelve birds diagnosed with WNV had injuries acquired just before death (e.g. bruises, bone fractures and ruptured internal organs). WNV targets many organs, and one of the common targets is the brain. Even if infection itself does not kill the bird, it may alter the bird's behaviour and lead to accidents or predation. Nine other infected birds concurrently had significant parasitic or fungal infections. Large numbers of parasites or fungal infections often are seen in debilitated animals. In these cases, WNV infection may not have been fatal on its own, but coupled with other infections, the birds' defenses likely were overwhelmed. 
Table 1. Species of wild birds from Saskatchewan with detectable West Nile Virus in 2007.

\begin{tabular}{|l|l|l|l|}
\hline Common name & $\begin{array}{l}\text { Number of dead } \\
\text { birds submitted } \\
\text { from June through } \\
\text { October, 2007 }\end{array}$ & $\begin{array}{l}\text { Number of birds } \\
\text { positive for West } \\
\text { Nile Virus }\end{array}$ & $\begin{array}{l}\text { Proportion of } \\
\text { birds positive for } \\
\text { West Nile Virus }\end{array}$ \\
\hline American Crow & 86 & 60 & $69.8 \%$ \\
\hline American Robin & 22 & 1 & $4.5 \%$ \\
\hline $\begin{array}{l}\text { American White } \\
\text { Pelican }\end{array}$ & 30 & 3 & $10 \%$ \\
\hline Black-billed Magpie & 18 & 12 & $66.7 \%$ \\
\hline Great Horned Owl & 13 & 3 & $23.1 \%$ \\
\hline Hawk (Buteo sp.) $)^{\mathrm{a}}$ & 1 & 1 & $100 \%$ \\
\hline Lesser Scaup & 6 & 3 & $50 \%$ \\
\hline Merlin & 25 & 20 & $80 \%$ \\
\hline Northern Goshawk & 2 & 2 & $100 \%$ \\
\hline Northern Harrier & 1 & 1 & $100 \%$ \\
\hline Pied-billed Grebe & 1 & 1 & $100 \%$ \\
\hline Prairie Falcon & 2 & 1 & $50 \%$ \\
\hline Red-tailed Hawk & 7 & 1 & $14.3 \%$ \\
\hline Ruffed Grouse & 1 & 1 & $100 \%$ \\
\hline Sharp-shinned Hawk & 1 & 1 & $100 \%$ \\
\hline Total & 240 & 111 & $46.3 \%$ \\
\hline
\end{tabular}

${ }^{\text {a }}$ This bird had not fledged and was not identified to species.

${ }^{\mathrm{b}}$ These three scaup were captive and held in outdoor pens

Finally, 27 infected birds were in poor to emaciated body condition. They may have been battling infection for some time, and were too ill to feed themselves properly. Alternately, if they were already in poor nutritional condition, they may have been more vulnerable to developing serious disease following infection.

It is clear from Table 1 that a wide range of bird species representing different families are susceptible to WNV. To date, at least 317 species of bird are known to be susceptible. ${ }^{3}$ This means that although WNV has caused or contributed to death in at least 15 different bird species from Saskatchewan, it has the potential to infect many more. Our method of WNV detection relies on carcasses, and favours species that suffer serious illness and die. In addition, the numbers presented here are based solely on dead birds found by the public and submitted for examination rather than on systematic research into WNV infection rates in wild birds. For this reason, 111 birds represents a gross underestimate of the actual number of birds that succumbed to infection in 2007. Theophilides et al. showed that the number of dead birds brought to laboratories such as the CCWHC is dependent on the number of people who report and submit them, rather than on the actual number of birds that died in the area. ${ }^{11}$ Much of Saskatchewan is rural and sparsely populated, and presumably many carcasses never are found. Visible species that live around human settlements like crows and magpies, and large birds such as birds of prey, tend to be detected and submitted in higher numbers than rural- or forestdwelling or smaller species. Carcasses that are not picked up, soon disappear because the ecosystem is very efficient at recycling organic matter. 
Hot summer temperatures, predators and scavengers result in rapid assimilation of carcasses into the environment before they are found.

\section{Effects on bird populations}

Impacts of WNV infection on individual birds can be dramatic (e.g. death), but impacts on wild bird populations are more difficult to assess and require estimates of population sizes. Although population data for most wild bird species are limited, Breeding Bird Surveys (BBS) and Christmas Bird Counts that have been conducted in North America offer some measure of population change over time. Using data collected from North American BBSs, La Deau et al. demonstrated continent-wide declines in seven bird species after the introduction of WNV in 1999. ${ }^{7}$ Six of these species (American Crow, Blue Jay, American Robin, Eastern Bluebird, Black-capped Chickadees and House Wren) are found in Saskatchewan. La Deau et al. also found striking regional declines for many bird species, particularly in eastern North America where WNV was first introduced and has been present for the longest period of time. ${ }^{7}$ These authors predict that, in a few years, more dramatic declines in bird populations may become evident in the west.

The Canadian Wildlife Service has published BBS data, by province, up to $2006 .{ }^{5}$ Of all of the species diagnosed with WNV in Saskatchewan in 2007, there has been a slight downward trend in abundance of crows and magpies from 2002 - 2006. Statistical analysis by decade showed that the decline in American Crows in Saskatchewan is significant, but it has been occurring since the 1970s, long before WNV was first detected in 2002. Crow populations were in decline at the time of WNV arrival in Saskatchewan, and WNV may have contributed to further decline, but this cannot be distinguished from the decline already in progress. BBS data from 2008 in Saskatchewan will be valuable in helping to detect any population effects of WNV following the outbreak in 2007.

Through its impact on bird populations, WNV also has the potential to alter ecosystem dynamics. Crows and magpies readily feed on carrion, which makes them important scavengers. In addition to removing rotting carcasses from the environment, crows and magpies are resistant to many bacteria and viruses that are potentially infectious for other species. By consuming dead animals, they decrease the persistence of potentially infectious or toxic material in the ecosystem. In the absence of crows and magpies, other scavenger species may proliferate. This could result in unpredictable new conflicts and management challenges, such as was seen in the Indian subcontinent following the decline of vultures and subsequent proliferation of feral dogs. ${ }^{9}$

Finally, WNV is a potential threat to certain threatened and endangered bird species, such as Greater SageGrouse populations in Saskatchewan. Although no Greater Sage-Grouse were submitted to the CCWHC in 2007, WNV was detected in Greater SageGrouse found dead in Alberta in 2003. Naugle et al. followed adult female sage-grouse in Alberta, Montana and Wyoming and documented a $25 \%$ decrease in survival during the WNV season in 2003. ${ }^{8}$ WNV therefore appears to be a real and additional threat to this endangered population.

\section{Summary}

The impacts of WNV on wild birds in Saskatchewan are varied and still poorly understood. WNV now is an 
established and, probably, permanent virus on the Canadian prairies. As the virus continues to cycle in wild birds in the province, it will be important to monitor bird populations in order to detect any impact on birds of Saskatchewan. Examination of sick and dead birds is one way to track the virus, but this method depends entirely upon the participation of people who find dead birds and send them to laboratories where cause of death can be determined. As summer approaches, residents of Saskatchewan can help track WNV by reporting and collecting dead birds. CCWHC welcomes all submissions of dead wildlife (fish, amphibians, reptiles, birds and mammals) as part of its disease surveillance program. Because WNV can infect humans, all carcasses should be handled with appropriate safety precautions. Please contact CCWHC for detailed instructions. ${ }^{2}$ Briefly, dead animals should not be touched with bare hands. Disposable or rubber gloves should be worn, or a sturdy plastic bag can be turned inside-out and used as a glove to pick up the carcass. Dead animals should be placed in two plastic bags, keeping the outer bag uncontaminated. Contaminated gloves can be removed and enclosed within the outer bag to facilitate appropriate disposal at the laboratory. If you are uncomfortable handling dead animals or have any questions, please contact the nearest Saskatchewan Environment office to report any carcasses, or contact the CCWHC regional centre in Saskatoon for more information. ${ }^{2}$

\section{Acknowledgements}

The author thanks the editors for their helpful comments on the manuscript.

1. CAFFREY, C., T.J. WESTON and S.C.R. SMITH. 2003. High mortality among marked crows subsequent to the arrival of West Nile Virus. Wildife Society Bulletin. 31: 870-872.
2. CANADIAN COOPERATIVE WILDLIFE HEALTH CENTRE. http://wildlife1.usask.ca/

3. CENTERS FOR DISEASE CONTROL website accessed on March 10, 2008 http://www.cdc.gov/ ncidod/dvbid/westnile/birdspecies.htm

4. CURRY, P. 2004. Saskatchewan mosquitoes and West Nile Virus. Blue Jay. 62(2): 104-111.

5. DOWNES, C.M. and B.T. COLLINS. 2007. Canadian bird trends web site version 2.2 . Canadian Wildlife Service, Environment Canada, Gatineau, Quebec, K1A OH3.

6. KOMAR, N., S. LANGEVIN, S. HINTEN, N. NEMETH, E. EDWARDS, D. HETTLER, B. DAVIS, R. BOWEN and M. BUNNING. 2003. Experimental infection of North American birds with the New York 1999 strain of West Nile virus. Emerging Infectious Diseases. 9: 311-322.

7. LA DEAU, S.L., A.M. KILPATRICK and P.P. MARRA. 2007. West Nile virus emergence and large-scale declines of North American bird populations. Nature. 447(7): 710-714.

8. NAUGLE, D.E., C.L. ALDRIDGE, B.L. WALKER, T.E. CORNISH, B.J. MOYNAHAN, M.J. HOLLORAN, K. BROWN, G.D. JOHNSON, E.T. SCHMIDTMANN, R.T. MAYER, C.Y. KATO, M.R. MATCHETT, T.J. CHRISTIANSEN, W.E. COOK, T. CREEKMORE, R.D. FALISE, E.T. RINKES and M.S. BOYCE. 2004. West Nile virus: pending crisis for greater sage-grouse. Ecology Letters. 7: 704-713.

9. PRAKESH, V., D.J. PAIN, A.A. CUNNINGHAM, P.F. DONALD, N. PRAKESH, A. VERMA, R. GARGI, S. SIVAKUMAR and A.R. RAHMANI. 2003. Catastrophic collapse of Indian white-backed Gyps bengalensis and long-billed Gyps indicus vulture populations. Biological Conservation. 109: 381-390.

10. PUBLIC HEALTH AGENCY OF CANADA website accessed on March 10, 2008 http:// www.phac-aspc.gc.ca/wnv-vwn/mon-hmnsurveng.php

11. THEOPHILIDES, C.N., S.C. AHEARN, S. GRADY and M. MERLINO. 2003. Identifying West Nile virus risk areas: The dynamic continuousarea space-time system. American Journal of Epidemiology. 157: 843-854.

12. YAREMYCH, S.A., R.E. WARNER, P.C. MANKIN, J.D. BRAWN, A. RAIM and R. NOVAK. 2004. West Nile virus and high death rate in American crows. Emerging Infectious Diseases. 10: 709-711. 